\title{
Analiza zmian parametrów mechanicznych kamieni cementowych dla kawernowych podziemnych magazynów gazu w zależności od czasu ich hydratacji
}

\begin{abstract}
Uszczelnienie kolumn rur okładzinowych w warstwach soli wymaga zastosowania specjalnie opracowanych zaczynów cementowych o długotrwałej odporności na jej działanie, dlatego bardzo istotne jest prowadzenie szczegółowych badań nad doborem odpowiednich receptur. W celu przygotowania właściwych składów należy podjąć i realizować innowacyjne badania laboratoryjne nad doborem rodzajów środków chemicznych i materiałów uszczelniających wpływających na polepszenie parametrów mechanicznych otrzymanych $\mathrm{z}$ nich kamieni cementowych. Celem zaprezentowanych w artykule badań była analiza wpływu środowiska solnego na zmiany parametrów technologicznych kamieni cementowych w czasie. Z wybranych do badań składów otrzymano kamienie cementowe, które poddawano długoterminowemu (do 12 miesięcy) działaniu solanki o pełnym nasyceniu. Po założonych okresach czasu badano ich parametry technologiczne. Zinterpretowanie uzyskanych wyników badań laboratoryjnych pozwoli na wytypowanie odpowiednich składów zaczynów cementowych mogących znaleźć zastosowanie podczas uszczelniania podziemnych magazynów gazu w kawernach solnych. Opracowane i wybrane receptury, dzięki swoim parametrom reologicznym oraz właściwościom mechanicznym kamieni cementowych, mogą być z powodzeniem stosowane podczas takich zabiegów. W wyniku przeprowadzonych badań laboratoryjnych opracowano receptury zaczynów cementowych na bazie solanki o pełnym nasyceniu jako wody zarobowej (wynika to z bezpośredniej obecności soli w otworze), które mogą znaleźć zastosowanie podczas uszczelniania kolumn rur okładzinowych w warunkach występowania pokładów soli.
\end{abstract}

Słowa kluczowe: kamień cementowy, magazyn gazu, parametry mechaniczne, kawerny solne, długoterminowe ekspozycje.

\section{Analysis of changes in mechanical parameters of cement stones for cavernous underground gas storage facilities, depending on the time of their hydration}

Sealing of casings in salt layers requires the use of specially developed cement slurries with long-lasting resistance, so it is important to conduct detailed research on the selection of suitable recipes. In order to prepare the right compositions, innovative laboratory tests on the selection of chemicals and sealing materials that improve the mechanical properties of the resulting cement stones. The aim of this article was to analyze the influence of salt environment on changes in technological parameters of cement stones over time. Cement stones samples were selected for long-term seasoning (12 months) in full saturated brine and their technological properties were examined for a predetermined period of time. Interpretation of the obtained results allows to identify appropriate cement slurries formulas with the potential for application in the sealing of underground gas storages in salt caverns. The developed and selected recipes thanks to proper rheological and mechanical parameters can be successfully used during such procedures. The aim of laboratory tests were to develop cement slurries based on fully saturated brine, as mixing water that can be used during sealing the casings in salt layers.

Key words: cement stone, gas storage, mechanical properties, salt caverns, long time exposure.

\section{Wprowadzenie}

Tworzenie kawerny solnej polega na wtłaczaniu wody do otworu, stopniowym rozpuszczaniu soli i odbiorze solanki.
Proces ługowania prowadzi się od dołu ku górze, przy stopniowym podnoszeniu kolumny rur ługowniczych oraz przy 
izolacji stropu. Strop otworu chroniony jest przez zastosowanie medium izolującego, np. oleju. W poszczególnych fazach tworzenia komory informacje o jej kształcie i objętości można uzyskać przy użyciu specjalnej echosondy zapuszczanej na kablu do otworu.

Po utworzeniu całej komory i sprawdzeniu jej szczelności można przystąpić do procesu pierwszego napełniania. Proces napełniania kawerny polega na zastąpieniu znajdującej się w komorze solanki gazem ziemnym oraz uzbrojeniu otworu wszystkimi niezbędnymi elementami.

Uszczelnienie kolumny rur okładzinowych w każdym otworze wiertniczym wymaga zastosowania specjalnie opracowanego i dobranego do danych warunków geologiczno-technicznych zaczynu cementowego. Wiercone otwory mogą różnić się od siebie między innymi głębokością, trajektorią, średnicą, rodzajem przewiercanych skał oraz ich przeznaczeniem. Na spodzie odwiertu panują także zróżnicowane wielkości ciśnienia i temperatury.

Wszystkie te czynniki mają znaczenie podczas opracowywania i sporządzania zaczynów cementowych, które powinny charakteryzować się odpowiednią gęstością, reologią, zerowym odstojem wody, jak najniższą filtracją i optymalnym czasem gęstnienia - w celu ich bezpiecznego zatłoczenia do otworu wiertniczego. Nie tylko właściwości zaczynu cementowego są istotne podczas zabiegów uszczelniania kolumn rur okładzinowych, ale ważne są również parametry mechaniczne powstałego z niego kamienia cementowego. Kamień cementowy powinien stworzyć w przestrzeni pozarurowej zbitą i szczelną barierę odporną na działające w otworze siły (ściskające, zginające i inne) oraz być nieprzepuszczalny dla wszelkich dopływających mediów.

Bardzo ważne podczas obecności soli w otworze wiertniczym (analogicznie do przypadku kawern solnych) jest zastosowanie zaczynów cementowych, z których zostały wytworzone kamienie cementowe wykazujące podwyższoną odporność na niszczące działanie soli w jak najdłuższym czasie.

Ze względu na zastosowanie zaczynów cementowych w bezpośrednim środowisku soli oraz z powodu warunków geologicznych, jakie moga panować w otworze wiertniczym, wykorzystywane podczas uszczelniania kolumn rur okładzinowych zaczyny cementowe powinny spełniać następujące kryteria:

- do ich sporządzania jako ciecz zarobową powinno się zastosować solankę o pełnym nasyceniu (gęstość $1,2 \mathrm{~g} / \mathrm{cm}^{3}$ ), ze względu na bezpośrednią obecność soli w otworze,

- powinny posiadać odpowiednią reologię (zapewniającą przetłaczalność) oraz czas gęstnienia (czas końca gęstnienia - czyli momentu, po którym zaczyn przestaje być przetłaczany - powinien być dłuższy od czasu potrzebnego na zatłoczenie danego zaczynu do otworu),
- powstały po związaniu zaczynu kamień cementowy powinien być odporny na niekorzystne działanie soli w czasie oraz posiadać wysokie parametry mechaniczne,

- zastosowany zaczyn cementowy powinien odznaczać się dodatnimi zmianami objętości (odznaczać się pęcznieniem) ze względu na elastyczność pokładów soli [9-12, 15-17].

Po przeanalizowaniu wyników badań laboratoryjnych przeprowadzonych na zaczynach cementowych wybrano te, które odznaczały się najlepszymi parametrami, a następnie wykorzystano je do dalszych badań próbek kamieni cementowych. Badania parametrów mechanicznych kamieni cementowych wykonywane były przy użyciu następującej aparatury:

- maszyna wytrzymałościowa,

- porozymetr rtęciowy,

- przepuszczalnościomierz gazowy.

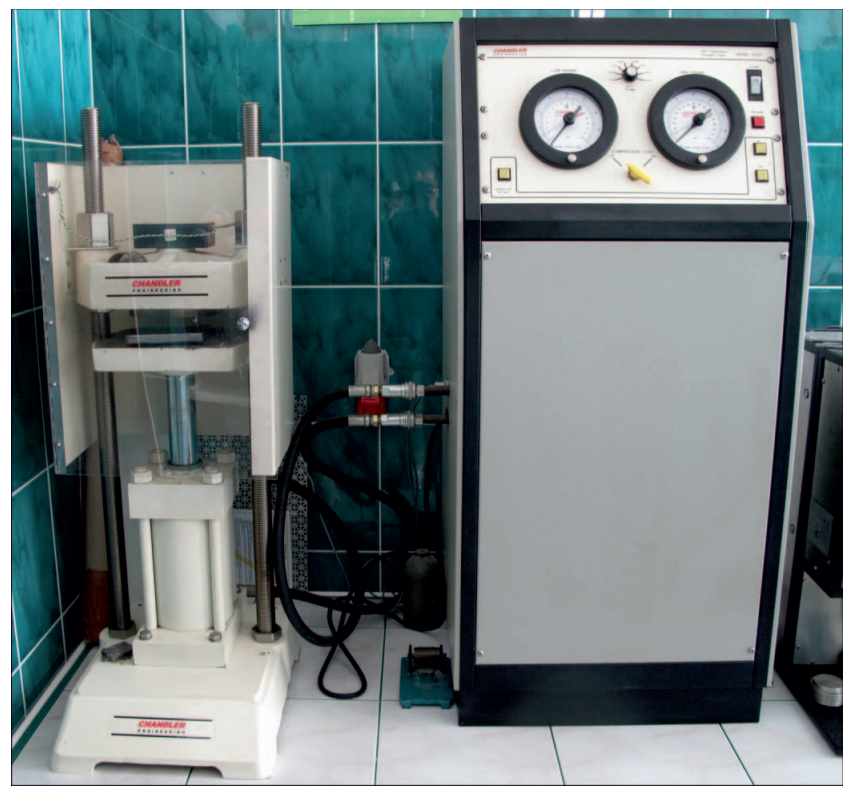

Fot. 1. Maszyna wytrzymałościowa

Maszyna wytrzymałościowa Model 4207 firmy Chandler pozwala na oznaczenie wytrzymałości na zginanie, ściskanie, rozciąganie i przyczepności kamienia cementowego do różnych materiałów. Dzięki urządzeniu można wywierać na próbkę nacisk do $180 \mathrm{kN}$. Jest to metoda niszcząca badaną próbkę.

Porozymetr rtęciowy Model 9500 firmy Micrometrics służy do oznaczania porowatości kamienia cementowego. Umożliwia on także pomiar całkowitej objętości porów, łącznej powierzchni porów, całkowitej objętości (\%), średniej średnicy porów oraz procentowego rozkładu rozmiaru porów. Dzięki odpowiedniemu oprogramowaniu można obliczyć powierzchnię właściwą oraz gęstość właściwą i szkieletową. Maksymalne ciśnienie pracy to $400 \mathrm{MPa}$, zakres pomiaru średnic wynosi od $360 \mu \mathrm{m}$ do 3,0 $\mathrm{nm}$. 


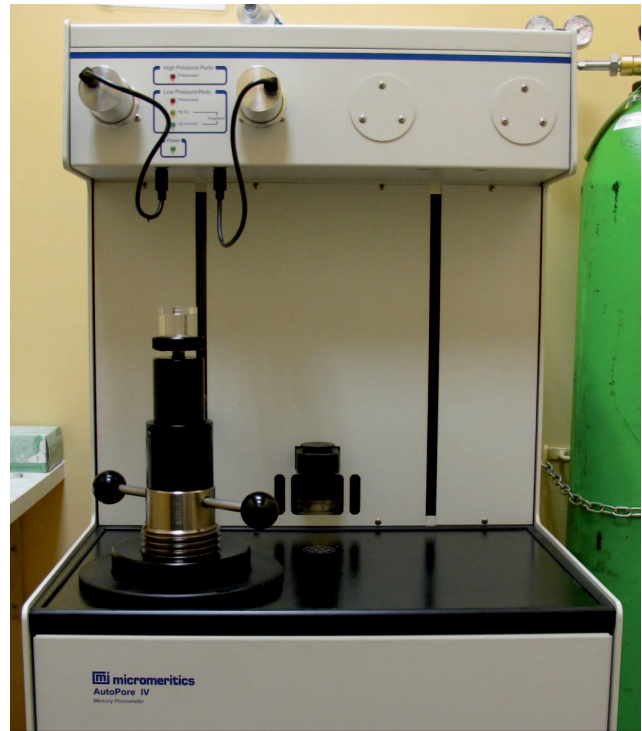

Fot. 2. Porozymetr rtęciowy

Badanie porowatości przy pomocy porozymetru rtęciowego polega na pomiarze objętości porów w analizowanej próbce na podstawie ilości rtęci wepchniętej w przestrzeń porową pod zadanym ciśnieniem. Na skutek wywołanego ciśnienia przez ciecz nieściśliwą i ściśliwość rtęci, długość słupa rtęci w rurce (penetrometrze), w której umieszczono próbkę, ulega zmniejszeniu, a rtęć wnika w przestrzeń porową badanego materiału. Ustalenie ilości rtęci, która spenetrowała strukturę porową próbki, a w związku z tym określenie objętości porów możliwe jest dzięki znanej zależność pomiędzy panującym ciśnieniem a ściśliwością rtęci [4].

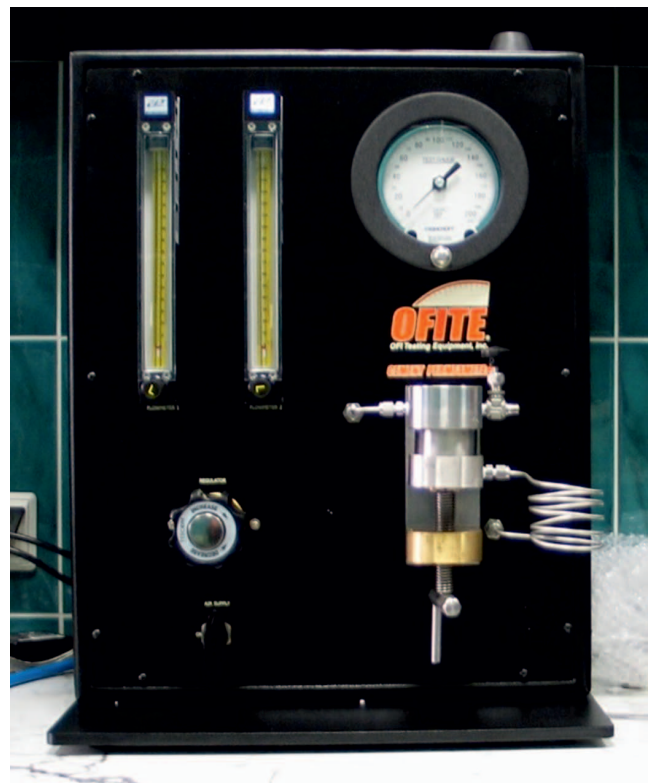

Fot. 3. Przepuszczalnościomierz gazowy

Badania przepuszczalności dla gazu kamieni cementowych wykonywano przy pomocy przepuszczalnościomierza firmy OFITE, który służy do mierzenia przepuszczalności próbek kamieni cementowych wielkości jednego cala. Oznaczenie polega na pomiarze czasu przepływu określonej objętości azotu przez cylindryczną próbkę kamienia cementowego pod stałą różnicą ciśnień. Próbki podlegają badaniom w temperaturze otoczenia. Wielkość ciśnienia wywieranego na badaną próbkę zależy od wielkości przepuszczalności próbki $[3,14]$.

\section{Badania laboratoryjne}

W artykule zamieszczono wyniki badań wybranych składów zaczynów cementowych, jak i otrzymanych z nich kamieni cementowych. Jako wody zarobowej użyto solanki o pełnym nasyceniu (solanka $\mathrm{NaCl}$ o gęstości $1,2 \mathrm{~g} / \mathrm{cm}^{3}$ ). Do sporządzania mieszanin wykorzystano trzy rodzaje cementu ( $\mathrm{G}$ - stosowany m.in. w otworach kawernowych w Mogilnie i Kosakowie oraz CEM II B/V 42,5 i CEM I 52,5 R - ze względu na podwyższoną odporność i wysokie parametry mechaniczne), mikrocement, gips modelowy (dodawany do zaczynu cementowego w celu zapobiegania jego skurczowi, a jednocześnie powodujący pęcznienie zaczynu) oraz inne dodatki wpływające na parametry reologiczne, czas gęstnienia, czas wiązania zaczynów oraz parametry mechaniczne powstałych z nich kamieni cementowych. Do solanki dodawano kolejno: środek odpieniający, upłynniający i obniżający filtrację oraz substancje regulujące czasy gęstnienia i wiązania. Pozostałe składniki, tj.: mikrocement, gips modelowy oraz cement, mieszano ze sobą, a następnie wprowadzano do wody zarobowej. Wszystkie komponenty dodawano do za- czynów w stosunku procentowym do masy suchego cementu. Odpowiednia głębokość występowania komory w soli wynosi od 700 do $2000 \mathrm{~m}$, dlatego badania przeprowadzono dla dwóch różnych wytypowanych warunków otworowych, jakie mogą występować na tej głębokości:

- temperatura $40^{\circ} \mathrm{C}$ i ciśnienie $20 \mathrm{MPa}$,

- temperatura $60^{\circ} \mathrm{C}$ i ciśnienie $30 \mathrm{MPa}$.

Po sporządzeniu zaczynów cementowych mierzono ich:

- gęstość,

- rozlewność,

- parametry reologiczne,

- odstój wody,

- filtrację,

- czas gęstnienia,

- czas wiązania,

- pęcznienie.

Po przeprowadzeniu badań laboratoryjnych zaczynów cementowych wytypowano te, które odznaczały się najlepszymi parametrami, a następnie wykonano z nich próbki kamieni 
cementowych. Otrzymane kamienie cementowe po założonych okresach czasu poddawano badaniom:

- wytrzymałości na ściskanie,

- wytrzymałości na zginanie,

- przyczepności do rur stalowych,

- porowatości,

- przepuszczalności dla gazu. Gęstość badanych zaczynów cementowych wahała się od 1,84 do $1,91 \mathrm{~g} / \mathrm{cm}^{3}$, zaś ich rozlewność mieściła się w przedziale od 170 do 200 mm. Dla każdego z wybranych do dalszych badań składów odnotowano dodatnie zmiany objętości zarówno po 24, jak i 48 godzinach. Wszystkie zaczyny nie wykazały odstoju wody. Poniżej przedstawiono wyniki badań właściwości reologicznych zaczynów cementowych oraz zmieniających się w czasie parametrów mechanicznych kamieni cementowych [5-8].

Niepewność uzyskanych wyników pomiarów zaprezentowanych poniżej oznaczono na podstawie klasy dokładności urządzeń pomiarowych na poziomie: $0,2 \%$ - dla pomiarów reologicznych, $0,4 \%$ - dla pomiarów wytrzymałości na ściskanie, zginanie, przyczepność do rur, 0,0001\% - dla porowatości, 0,001\% - dla przepuszczalności.

\section{W temperaturze $60^{\circ} \mathrm{C}$}

Sklad zaczynu nr 3

Solanka $\mathrm{NaCl}$ o gęstości $1,2 \mathrm{~g} / \mathrm{cm}^{3} \quad$ w/c $=\mathbf{0 , 6 0}$

Odpieniacz $\quad 1,0 \%$

Upłynniacz $\quad 0,5 \%$

Antyfiltrat $\quad 0,5 \%$

Mikrocement $\quad \mathbf{1 0 , 0 \%}$

Cement G $\quad 100 \%$

Gips modelowy $\quad \mathbf{5 , 0} \%$

Środek spęczniający $\quad 0,2 \%$
Środek spęczniający $\quad 0,2 \%$

Odpieniacz $\quad 0,5 \%$

Upłynniacz $\quad 0,5 \%$

Antyfiltrat

$\mathrm{CaCl}_{2}$

Mikrocement

Gips modelowy

Środek spęczniający
Solanka $\mathrm{NaCl}$ o gęstości $1,2 \mathrm{~g} / \mathrm{cm}^{3} \quad$ w/c $=\mathbf{0 , 6 2}$

Odpieniacz $\quad 0,5 \%$

Upłynniacz $\quad 0,5 \%$

Antyfiltrat $\quad 0,1 \%$

Opóźniacz wiązania $\quad 0,4 \%$

Mikrocement $\quad \mathbf{1 0 , 0} \%$

Cement CEM I 52,5 R $\quad 100 \%$

Gips modelowy $\quad \mathbf{5 , 0} \%$

Środek spęczniający $\quad 0,2 \%$

Wytrzymałość kamienia cementowego nr 1 na ściskanie po 2 i 7 dniach wynosiła około 14,0 MPa, następnie wzrosła i po 6 miesiącach była na poziomie 41,0 MPa. Kolejne badanie wytrzymałości na ściskanie po 12 miesiącu wykazało jej spadek do 34,3 MPa. Przyczepność kamienia do rur stalowych po każdym okresie badania była coraz wyższa, zaś jego wytrzymałość na zginanie przez cały okres sezonowania próbek nie uległa zmianie.

Porowatość kamienia cementowego nr 1 przez pierwsze pół roku była coraz niższa i ostatecznie wyniosła 28,1\%. Kolejny pomiar porowatości po 12 miesiącu utrzymywał się na

Tablica 1. Zestawienie najważniejszych wyników badań zaczynów cementowych

\begin{tabular}{|c|c|c|c|c|c|c|c|c|c|c|}
\hline \multirow{2}{*}{$\begin{array}{c}\text { Temperatura } \\
{\left[{ }^{\circ} \mathrm{C}\right]}\end{array}$} & \multirow{2}{*}{$\begin{array}{c}\mathrm{Nr} \\
\text { zaczynu }\end{array}$} & \multirow{2}{*}{$\begin{array}{l}\text { Gęstość } \\
{\left[\mathrm{g} / \mathrm{cm}^{3}\right]}\end{array}$} & \multirow{2}{*}{$\begin{array}{c}\text { Rozlewność } \\
{[\mathrm{mm}]}\end{array}$} & \multirow{2}{*}{$\begin{array}{c}\text { Odstój } \\
\text { wody } \\
{[\%]}\end{array}$} & \multirow{2}{*}{$\begin{array}{c}\text { Lepkość } \\
\text { plastyczna } \\
{[\mathrm{mPa} \cdot \mathrm{s}]}\end{array}$} & \multirow{2}{*}{$\begin{array}{c}\text { Granica } \\
\text { płynięcia } \\
{[\mathrm{Pa}]}\end{array}$} & \multicolumn{2}{|c|}{$\begin{array}{c}\text { Czas gęstnienia } \\
\text { [h-min] }\end{array}$} & \multicolumn{2}{|c|}{$\begin{array}{c}\text { Zmiany objętości } \\
{[\%]}\end{array}$} \\
\hline & & & & & & & $30 \mathrm{Bc}$ & $100 \mathrm{Bc}$ & 24 godz. & 48 godz. \\
\hline \multirow{2}{*}{$40^{\circ} \mathrm{C}$} & 1 & 1,84 & 170 & 0,0 & 151,5 & 18,0 & $2-44$ & $6-47$ & $+0,137$ & $+0,141$ \\
\hline & 2 & 1,86 & 185 & 0,0 & 102,0 & 17,8 & $5-38$ & $7-54$ & $+0,141$ & $+0,145$ \\
\hline \multirow{2}{*}{$60^{\circ} \mathrm{C}$} & 3 & 1,91 & 190 & 0,0 & 147,6 & 17,2 & $>7 \mathrm{~h}$ & $<20 \mathrm{~h}$ & $+0,137$ & $+0,141$ \\
\hline & 4 & 1,90 & 200 & 0,0 & 96,0 & 15,4 & $3-24$ & $4-00$ & $+0,138$ & $+0,144$ \\
\hline
\end{tabular}

Tablica 2. Parametry mechaniczne kamienia cementowego $\mathrm{nr} 1$.

Cement CEM II B/V 42,5, mikrocement 10,0\%, gips 5,0\%, $40^{\circ} \mathrm{C}, 20 \mathrm{MPa}$

\begin{tabular}{|c|c|c|c|c|c|c|c|}
\hline & \\
\hline & $\begin{array}{c}\mathrm{T} \\
{\left[{ }^{\circ} \mathrm{C}\right]}\end{array}$ & $\begin{array}{c}\text { Po } 2 \\
\text { dniach }\end{array}$ & $\begin{array}{c}\text { Po } 7 \\
\text { dniach }\end{array}$ & $\begin{array}{l}\text { Po } 14 \\
\text { dniach }\end{array}$ & $\begin{array}{l}\text { Po } 28 \\
\text { dniach }\end{array}$ & $\begin{array}{c}\text { Po } 6 \\
\text { miesiącach }\end{array}$ & $\begin{array}{c}\text { Po } 12 \\
\text { miesiącach }\end{array}$ \\
\hline Wytrzymałość na ściskanie [MPa] & \multirow{5}{*}{40} & 14,5 & 13,0 & 30,0 & 36,0 & 40,8 & 34,3 \\
\hline Przyczepność do rur [MPa] & & 3,5 & 4,5 & 5,1 & 5,2 & 9,0 & 9,3 \\
\hline Wytrzymałość na zginanie [MPa] & & 10,5 & 10,5 & 10,5 & 10,5 & 10,5 & 9,0 \\
\hline Porowatość [\%] & & 35,2 & 36,2 & 30,9 & 30,1 & 28,1 & 32,4 \\
\hline Przepuszczalność [mD] & & 0,06 & 0,35 & 0,4 & 0,37 & 0,32 & 0,33 \\
\hline
\end{tabular}



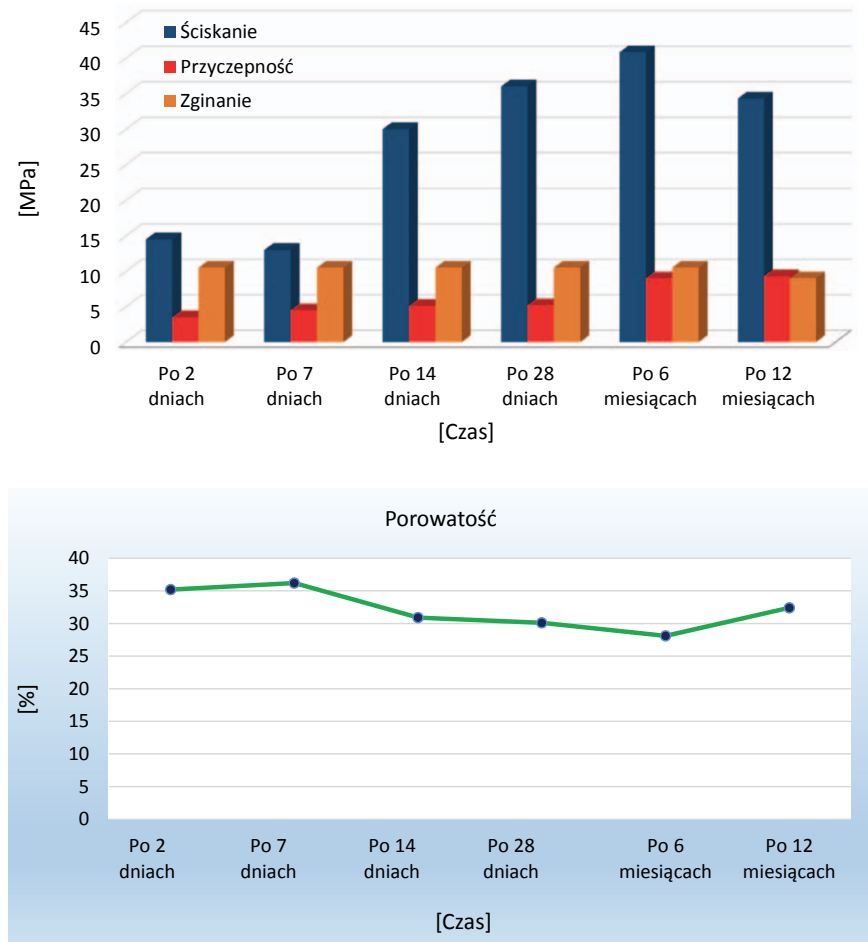

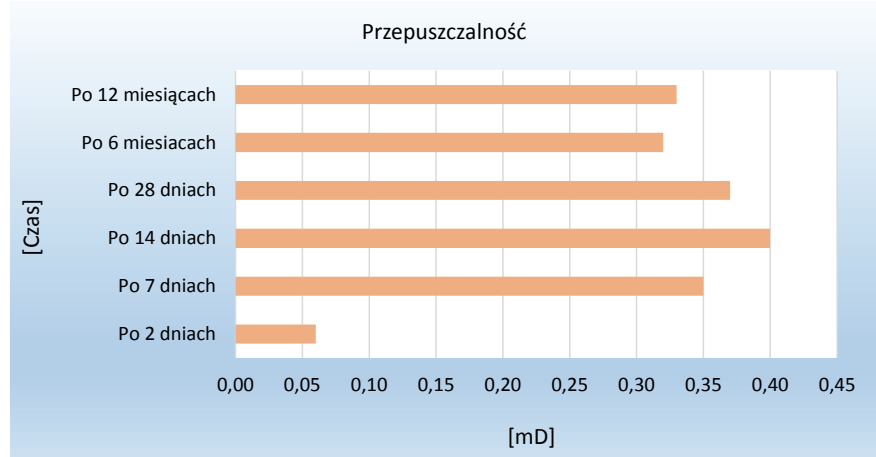

poziomie $32,4 \%$. Przepuszczalność dla gazu po każdym badaniu nie przekraczała $0,4 \mathrm{mD}$.

Wytrzymałość kamienia cementowego nr 2 na ściskanie po 2 dniach wyniosła $14,8 \mathrm{MPa}$. Następnie z upływem czasu wzrastała i po 6 miesiącach była na poziomie $38,4 \mathrm{MPa}$. Kolejny pomiar wykazał spadek wytrzymałości o 10,0 MPa. Przyczepność kamienia do rur stalowych z każdym badaniem była coraz wyższa, natomiast wytrzymałość kamienia cementowego na zginanie przez 12 miesięcy nie ulegała większym zmianom.

Tablica 3. Parametry mechaniczne kamienia cementowego $\mathrm{nr} 2$.

Cement CEM II B/V 42,5, mikrocement 10,0\%, gips 5,0\%, $40^{\circ} \mathrm{C}, 20 \mathrm{MPa}$

\begin{tabular}{|c|c|c|c|c|c|c|c|}
\hline & \\
\hline & $\begin{array}{c}\mathrm{T} \\
{\left[{ }^{\circ} \mathrm{C}\right]}\end{array}$ & $\begin{array}{c}\text { Po } 2 \\
\text { dniach }\end{array}$ & $\begin{array}{c}\text { Po } 7 \\
\text { dniach }\end{array}$ & $\begin{array}{l}\text { Po } 14 \\
\text { dniach }\end{array}$ & $\begin{array}{l}\text { Po } 28 \\
\text { dniach }\end{array}$ & $\begin{array}{c}\text { Po } 6 \\
\text { miesiącach }\end{array}$ & $\begin{array}{c}\text { Po } 12 \\
\text { miesiącach }\end{array}$ \\
\hline Wytrzymałość na ściskanie [MPa] & \multirow{5}{*}{40} & 14,8 & 17,8 & 19,0 & 20,0 & 38,4 & 28,7 \\
\hline Przyczepność do rur [MPa] & & 3,4 & 3,8 & 4,0 & 5,5 & 9,7 & 8,9 \\
\hline Wytrzymałość na zginanie [MPa] & & 10,5 & 10,5 & 9,0 & 10,5 & 10,5 & 9,0 \\
\hline Porowatość [\%] & & 35,4 & 39,0 & 34,2 & 29,8 & 26,8 & 33,5 \\
\hline Przepuszczalność [mD] & & 0,49 & 0,44 & 0,38 & 0,26 & 0,20 & 0,30 \\
\hline
\end{tabular}
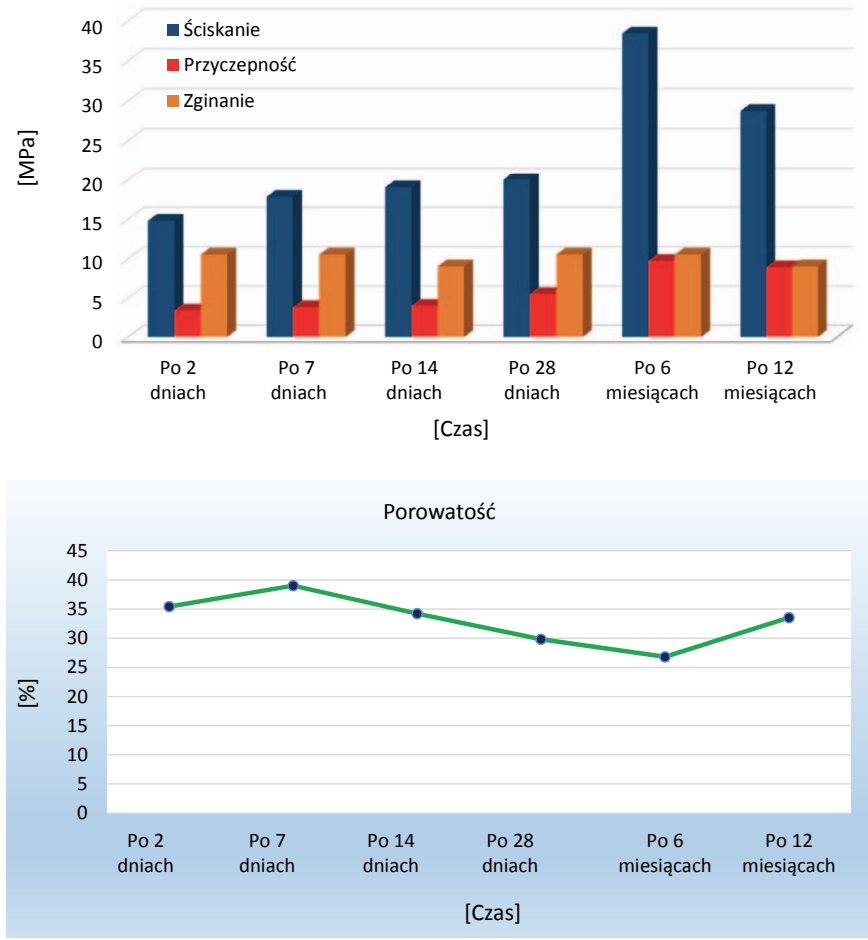

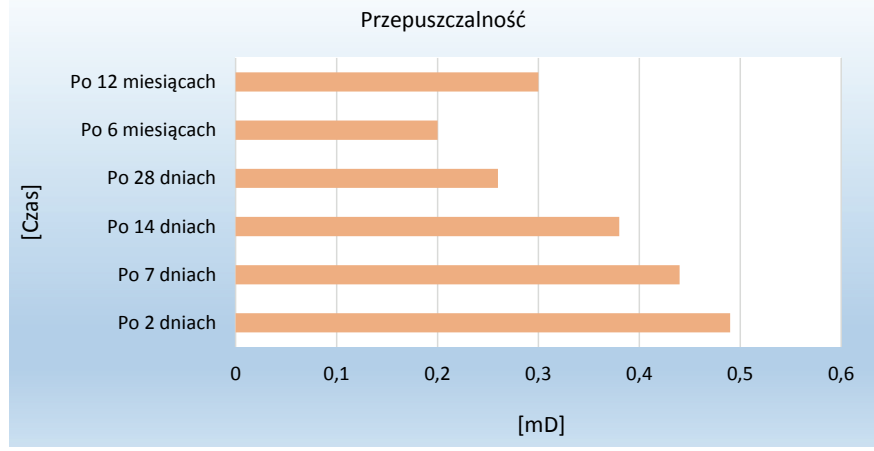

Porowatość kamienia cementowego po 2 dniach jego hydratacji wynosiła 35,4\%. Po 12 miesiącach sezonowania próbek wartość porowatości nieznacznie zmalała do 33,5\%. Przepuszczalność próbki kamienia cementowego nr 2 po roku osiągnęła wartość $0,3 \mathrm{mD}$.

Wytrzymałość kamienia cementowego nr 3 na ściskanie po 2 dniach wyniosła 15,0 MPa. Następnie wartość ta wzrosła i utrzymywała się na poziomie około $29 \mathrm{MPa}$ po 28 dniach. Ostatnie badania wytrzymałości na ściskanie po 12 miesiącach dało wynik 36,9 MPa. Przyczepność kamienia 
Tablica 4. Parametry mechaniczne kamienia cementowego nr 3.

Cement $\mathrm{G}$, mikrocement $10,0 \%$, gips $5,0 \%, 60^{\circ} \mathrm{C}, 30 \mathrm{MPa}$

\begin{tabular}{|c|c|c|c|c|c|c|c|}
\hline & $\begin{array}{c}\mathrm{T} \\
{\left[{ }^{\circ} \mathrm{C}\right]}\end{array}$ & $\begin{array}{c}\text { Po } 2 \\
\text { dniach }\end{array}$ & $\begin{array}{c}\text { Po } 7 \\
\text { dniach }\end{array}$ & $\begin{array}{l}\text { Po } 14 \\
\text { dniach }\end{array}$ & $\begin{array}{l}\text { Po } 28 \\
\text { dniach }\end{array}$ & $\begin{array}{c}\text { Po } 6 \\
\text { miesiącach }\end{array}$ & $\begin{array}{c}\text { Po } 12 \\
\text { miesiącach }\end{array}$ \\
\hline Wytrzymałość na ściskanie [MPa] & \multirow{5}{*}{60} & 15,0 & 29,8 & 29,3 & 29,1 & 36,1 & 36,9 \\
\hline Przyczepność do rur [MPa] & & 4,8 & 5,2 & 5,6 & 5,8 & 7,0 & 8,7 \\
\hline Wytrzymałość na zginanie [MPa] & & 9,0 & 12,0 & 13,5 & 13,5 & 16,5 & 16,5 \\
\hline Porowatość [\%] & & 31,0 & 31,3 & 31,4 & 30,7 & 28,3 & 31,6 \\
\hline Przepuszczalność [mD] & & 0,48 & 0,37 & 0,50 & 0,39 & 0,21 & 0,14 \\
\hline
\end{tabular}
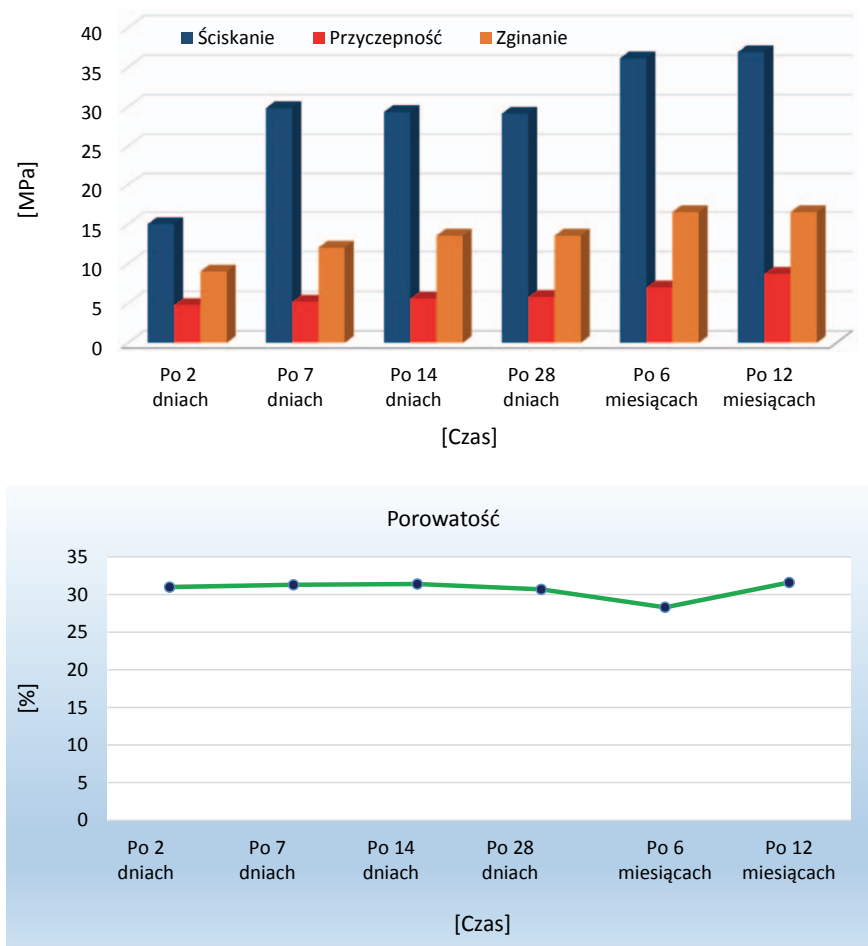

do rur stalowych oraz jego wytrzymałość na zginanie przez cały okres sezonowania próbek wzrastały.

Porowatość kamienia cementowego po 2 dniach jego hydratacji wynosiła 31,0\%. Po 12 miesiącach sezonowania próbek wartość porowatości nieznacznie wzrosła do 31,6\%. Przepuszczalność próbki kamienia cementowego nr 3 po roku osiągnęła wartość $0,14 \mathrm{mD}$ i w porównaniu do pierwszego badania po 2 dniach spadła o $0,34 \mathrm{mD}$.

Wartości wytrzymałości na ściskanie, zginanie oraz przyczepność do rur stalowych kamienia cementowego nr 4 wy-

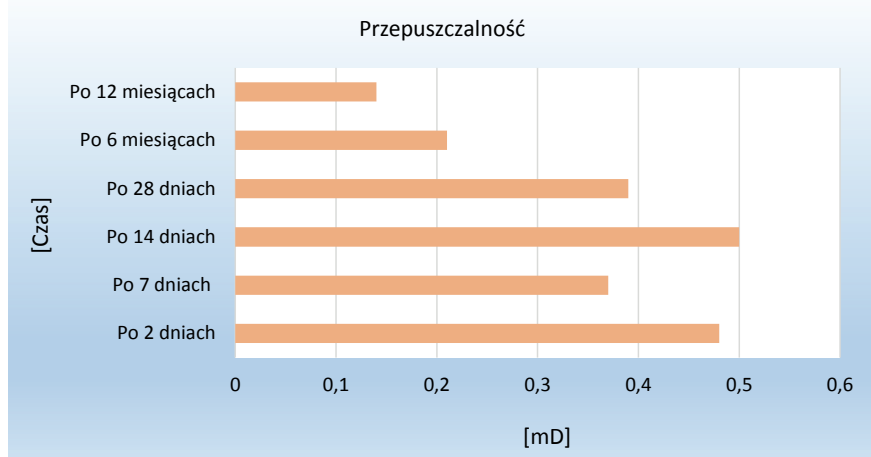

konanego z zaczynu nr 4 wzrosły między 2 dniem a 6 miesiącem od ich wykonania.

Porowatość próbki nr 4 do 28 dnia jej sezonowania utrzymywała się na zbliżonym poziomie (około $32,5 \%$ ), po tym okresie nastąpił jej wzrost do $35,4 \%$ po 6 miesiącach. Badania przepuszczalności dla gazu ujawniły jej spadek wraz z upływem czasu i po 6 miesiącach wynosiła ona $0,16 \mathrm{mD}$.

Wytypowane zaczyny cementowe opracowane zostały na bazie cementu G (zaczyn nr 3), cementu CEM II B/V 42,5 (zaczyny nr 1 i 2) i cementu CEM I 52,5 R (zaczyn nr 4). Zaczyny cementowe wytypowane dla temperatury $60^{\circ} \mathrm{C}$ odznaczały się gęstością od $1,90 \mathrm{~g} / \mathrm{cm}^{3}$ do $1,91 \mathrm{~g} / \mathrm{cm}^{3}$. Oba zaczyny nie posiadały odstoju wody. Zaczyn cementowy nr 3 nie osiągnął początku gęstnienia do $6 \mathrm{~h} 30 \mathrm{~min}$. Natomiast zaczyn cementowy nr 4 posiadał czasy gęstnienia odpowiednie dla wymaganego czasu tłoczenia $\mathrm{w}$ danych warunkach otworowych.

Otrzymane próbki kamieni cementowych odznaczały się dobrymi parametrami mechanicznymi po każdym okresie badania. Wytrzymałość kamienia cementowego nr 3 na ściskanie

Tablica 5. Parametry mechaniczne kamienia cementowego $\mathrm{nr} 4$.

Cement CEM I 52,5 R, mikrocement $10,0 \%$, gips $5,0 \%, 60^{\circ} \mathrm{C}, 30 \mathrm{MPa}$

\begin{tabular}{|c|c|c|c|c|c|c|c|}
\hline & $\begin{array}{c}\mathrm{T} \\
{\left[{ }^{\circ} \mathrm{C}\right]}\end{array}$ & Po 2 dniach & Po 7 dniach & $\begin{array}{l}\text { Po } 14 \\
\text { dniach }\end{array}$ & $\begin{array}{l}\text { Po } 28 \\
\text { dniach }\end{array}$ & $\begin{array}{c}\text { Po } 3 \text { miesią- } \\
\text { cach }\end{array}$ & $\begin{array}{c}\text { Po } 6 \text { miesią- } \\
\text { cach }\end{array}$ \\
\hline Wytrzymałość na ściskanie [MPa] & \multirow{5}{*}{60} & 23,8 & 29,5 & 26,5 & 36,3 & 31,0 & 40,5 \\
\hline Przyczepność do rur [MPa] & & 3,8 & 5,8 & 6,0 & 7,4 & 4,6 & 8,1 \\
\hline Wytrzymałość na zginanie [MPa] & & 13,5 & 15,0 & 16,5 & 16,5 & 15,0 & 15,0 \\
\hline Porowatość [\%] & & 32,6 & 31,9 & 30,9 & 32,7 & 34,4 & 35,4 \\
\hline Przepuszczalność [mD] & & 0,48 & 0,44 & 0,39 & 0,31 & 0,28 & 0,16 \\
\hline
\end{tabular}



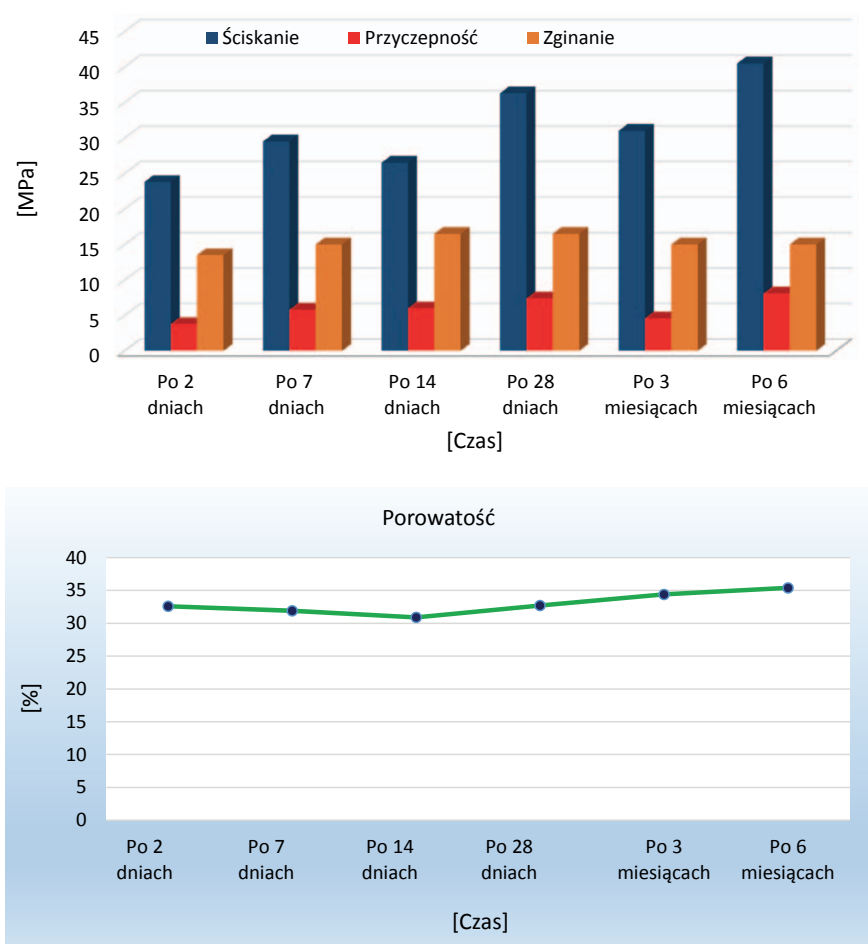

po 2 dniach wynosiła $15,0 \mathrm{MPa}$, zaś po 12 miesiącach wzrosła do 36,9 MPa. Przyczepność kamienia do rur stalowych oraz jego wytrzymałość na zginanie wzrastały przez cały okres sezonowania próbek. Porowatość kamienia cementowego po 2 dniach jego hydratacji wynosiła 31,0\%. Po 12 miesiącach sezonowania próbek wartość porowatości nieznacznie wzrosła do 31,6\%. Przepuszczalność próbki kamienia cementowego $\mathrm{nr} 3$ po roku wyniosła $0,14 \mathrm{mD}$. W przypadku próbek otrzymanych ze składu nr 4 wartości wytrzymałości na ści-

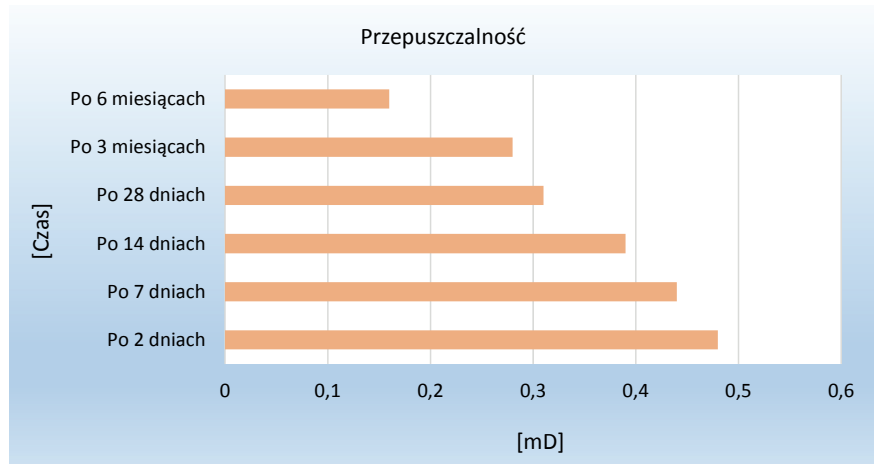

skanie, zginanie oraz przyczepność do rur stalowych wzrosły między 2 dniem a 6 miesiącem od ich wykonania. Porowatość próbki nr 4 do 28 dnia jej sezonowania utrzymywała się na zbliżonym poziomie - około $32,5 \%$, po tym okresie nastąpił jej wzrost do $35,4 \%$ po 6 miesiącach. Badania przepuszczalności dla gazu ujawniły jej spadek wraz z upływem czasu i po 6 miesiącach wynosiła ona $0,16 \mathrm{mD}$.

Najlepsze składy wytypowane dla temperatury $40^{\circ} \mathrm{C}$ miały gęstości od $1,84 \mathrm{~g} / \mathrm{cm}^{3}$ do $1,86 \mathrm{~g} / \mathrm{cm}^{3}$. Oba zaczyny nie posiadały odstoju wody. Zaczyny osiągnęły koniec gęstnienia poniżej 8 godzin. Czas ten można z powodzeniem regulować.

W przypadku obu próbek kamienia cementowego (1 1 i 2$)$ nastąpił wzrost ich wytrzymałości na ściskanie wraz z upływem czasu (nr 1 - 34,3 MPa po 12 miesiącach; nr 2 28,7 MPa po 12 miesiącach). Analogiczna sytuacja wystąpiła przy badaniach ich przyczepności do rur stalowych. Badania porowatości dla obu próbek wytypowanych dla temperatury $40^{\circ} \mathrm{C}$ wykazały jej spadek wraz z upływem czasu sezonowania w warunkach otworopodobnych $[1,2,13]$.

\section{Wnioski}

Na podstawie przeprowadzonych badań wytypowanych składów zaczynów cementowych można wyciągnąć następujące wnioski:

1. Większość poddanych badaniom składów zaczynów cementowych charakteryzowała się dobrymi parametrami reologicznymi oraz zerowym odstojem wody.

2. Gęstości zaczynów cementowych wahały się w przedziale od $1,84 \mathrm{~g} / \mathrm{cm}^{3}$ do $1,91 \mathrm{~g} / \mathrm{cm}^{3}$.

3. Receptury opracowane na bazie cementów CEM II B/V 42,5 i CEM I 52,5 R uzyskiwały czasy gęstnienia odpowiednie dla warunków otworowych, jakie mogą panować podczas ich zatłaczania do otworu. Czasy te w razie potrzeby można swobodnie regulować środkiem opóźniającym lub przyśpieszającymi wiązanie. Zaczyn cementowy sporządzony na bazie cementu $\mathrm{G}$ po czasie $6 \mathrm{~h} 30 \mathrm{~min}$ nie osiągnął początku gęstnienia.

4. Wszystkie parametry opracowanych składów zaczynów uszczelniających $\mathrm{w}$ razie potrzeby można $\mathrm{z}$ powodzeniem regulować, zmieniając ilości procentowe zastosowanych dodatków.

5. Dodatek gipsu modelowego do składów zaczynów cementowych wpływał na zwiększenie ich pęcznienia podczas wiązania.

6. Pęcznienie w zależności od składu i ilości dodawanego gipsu wynosiło od $0,137 \%$ - po 24 godzinach, do $0,145 \%$ - po 48 godzinach od zarobienia zaczynu.

7. Badania laboratoryjne parametrów mechanicznych kamieni cementowych przetrzymywanych w temperaturach 40 i $60^{\circ} \mathrm{C}$ wykazały, że już po 2 dniach ich wytrzymałości na ściskanie przekraczały 14,0 MPa, na zginanie 7,0 MPa, a przyczepność do rur stalowych przekraczała 3,0 MPa (z wyjątkiem składu nr 2).

8. Większość badanych próbek kamieni cementowych wraz z upływem czasu odznaczała się wzrostem parametrów mechanicznych.

Celem przeprowadzonych badań było opracowanie za- 
czynów uszczelniających do otworów przeznaczonych pod kawernowe podziemne magazyny gazu (KPMG) o temperaturze dynamicznej do $60^{\circ} \mathrm{C}$. Uszczelnienie kolumn rur okładzinowych w warstwach soli wymaga zastosowania specjalnie opracowanych zaczynów cementowych o długotrwałej odporności na jej działanie, dlatego bardzo istotne jest prowadzenie szczegółowych badań nad doborem odpowiednich receptur.
Zinterpretowanie uzyskanych wyników badań laboratoryjnych pozwoli na wytypowanie odpowiednich składów zaczynów cementowych mogących znaleźć zastosowanie podczas uszczelniania podziemnych magazynów gazu w kawernach solnych. Opracowane i wybrane składy, dzięki swoim parametrom reologicznym oraz właściwościom mechanicznym kamieni cementowych, mogą być z powodzeniem stosowane podczas takich zabiegów.

Prosimy cytować jako: Nafta-Gaz 2017, nr 6, s. 387-394, DOI: 10.18668/NG.2017.06.03

Artykuł nadesłano do Redakcji 9.12.2016 r. Zatwierdzono do druku 20.03.2017 r.

Artykuł powstał na podstawie pracy statutowej pt.: Analiza zmian parametrów mechanicznych kamieni cementowych dla KPMG w zależności od czasu ich ekspozycji - praca INiG - PIB na zlecenie MNiSW; nr zlecenia: 0042/KW/16/01, nr archiwalny: DK-4100-42/16.

\section{Literatura}

[1] Dębińska E.: Ocena działania dodatków opóźniających czas wiazania zaczynów cementowych na podstawie badań laboratoryjnych. Nafta-Gaz 2012, nr 4, s. 225-232.

[2] Giergiczny Z. i in.: Cementy w ofercie handlowej Górażdże Cement S.A. Chorula, październik 2003.

[3] Instrukcja obsługi przepuszczalnościomierza firmy OFITE. Model 120-87.

[4] Kremieniewski M.: Modyfikacja przestrzeni porowej kamieni cementowych. Nafta-Gaz 2012, nr 3, s. 165-170.

[5] Kremieniewski M.: Wplyw warunków hydratacji na strukturę przestrzenna kamieni cementowych. Nafta-Gaz 2013, nr 1, s. 51-56.

[6] Kremieniewski M., Stryczek S., Kotwica L.: Zmiany w mikrostrukturze płaszcza cementowego w zależności od warunków hydratacji zaczynu. Nafta-Gaz 2014, nr 12, s. 918-925.

[7] Kurdowski W.: Chemia cementu i betonu. Wydawnictwo Naukowe PWN, Warszawa 2010.

[8] Kut Ł.: Wplyw mikrocementu na parametry zaczynu i kamienia cementowego. Nafta-Gaz 2011, nr 12, s. 903-908.

[9] Laskowska T.: Underground gas storage in salt caverns. Polish Market 2012, nr 9, s. 28-29.

[10] Laskowska T., Gąska K.: Nowe metody i technologie zastosowane $w$ czasie tugowania komór, przy budowie magazynów gazu zlokalizowanych w złożach soli. Nafta-Gaz 2010 , nr 5, s. 356-361.

[11] Rzepka M.: Badania dtugookresowej odporności korozyjnej stwardnialych zaczynów cementowych stosowanych w wiertnictwie. Nafta-Gaz 2015, nr 7, s. 451-460.
[12] Stopa J., Rychlicki S., Kosowski P.: Rola podziemnego magazynowania gazu w kawernach solnych. Gospodarka Surowcami Mineralnymi 2008, tom 24, zeszyt 3/2.

[13] Strona internetowa: http://infohost.nmt.edu/ petro/faculty/ Engler571/Chapter6-Permeability.pdf (dostęp: 4.07.2016).

[14] Strona internetowa: http://pl.wikipedia.org/wiki/Przepuszczalno\%C5\%9B\%C4\%87_\%28hydrodynamika\%29 (dostęp: 23.03.2016).

[15] Strona internetowa: http://www.ipt.ntnu.no/ jsg/undervisning/naturgass/parlaktuna/Chap9.pdf (dostęp: 14.04.2016).

[16] Strona internetowa: http://www.netl.doe.gov/File\%20Library/Publications/brochures/SaltCav.pdf (dostęp: 27.09.2016).

[17] Strona internetowa: https://www.slb.com/ /media/Files/resources/oilfield review/ors02/sum02/p2 17.pdf (dostęp: $5.07 .2016)$

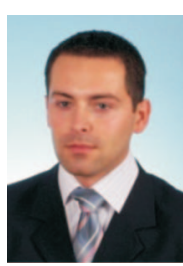

Mgr inż. Łukasz KUT

Asystent w Zakładzie Technologii Wiercenia. Instytut Nafty i Gazu - Państwowy Instytut Badawczy ul. Lubicz 25 A

31-503 Kraków

E-mail:lukasz.kut@inig.pl 